\title{
ASSESSING OF LANDSCAPE POTENTIAL FOR WATER MANAGEMENT REGARDING ITS SURFACE WATER (USING THE EXAMPLE OF THE MICRO-REGION MINČOL)
}

\author{
LUCIA KUNÁKOVÁ
}

Department of Tourism and Hotel Management, Faculty of Management, University of Prešov, Konštantínova 16, 08001 Prešov, Slovak Republic; e-mail:lkunakova@gmail.com

\begin{abstract}
Kunáková L.: Assessing of landscape potential for water management regarding its surface water (using the example of the micro-region Minčol). Ekológia (Bratislava), Vol. 35, No. 2, p. 148-159, 2016.

The presence of water is one of the decisive factors of landscape's natural potential. Water affects landscape's predisposition for agricultural production, water supply available to the wide population and industry (the most important is the yield of water resources). Ponds, lakes and other water areas are zones of recreation and relaxation. Near sources mineral water, several world-famous spas were build. Waterways are also used to generate electricity. Geothermal underground water represents a very significant landscape potential. Determining hydrological potential of the area is important for the regional development. This paper assesses the landscape potential for water management regarding its surface waters in the micro-region Minčol. The micro-region was divided by a square grid, and for each square, we determined the appropriateness of this potential based on score points. The determining evaluation criteria were static reserves of surface water, waterway ranking and annual average discharge. First, we determined the significance (value) of individual criteria (classification characteristics), and then we calculated the values of individual classifiers, which were then multiplied by the value of the individual classifier intervals. The summary of points in each square belongs to a particular degree of suitability for water management based on surface waters. The potential was divided into five degrees (intervals): very unfavourable potential, unfavourable potential, moderately favourable potential, favourable potential and very favourable potential.
\end{abstract}

Key words: landscape potential, water management, surface water, micro-region Minčol.

\section{Introduction}

One of the frequently used terms related to the landscape research is potential. The issue of assessing the landscape potential and defining the nature of this concept is elaborated in a variety of works, especially from the fields of ecology and geography. Landscape ecology started to be studied in more detail at the Leipzig Landscape Ecology School (Neef, 1963; Haase, 1964; Jäger, Hrabowski, 1976; Jäger et al., 1977; Mannsfeld, 1978, 1979; Barsch, 1980; Mannsfeld, 1983; Mosimann, 1984; Haase, 1991; Bastian, Schreiber, 1994; Leser, 1997, and others). Neef (1966) defined a regional-economic potential as 'the sum of all landscape features that create conditions for economic appreciation of the landscape with its materials and energy forming its structure. Graf 
(1976) used the term 'natural potential' and defined it as 'the ability of a particular area to provide substances and energy, to a reasonable extent, for production and consumption purposes. Haase (1978) defined natural (natural-space) potential as a 'natural content of the landscape with its material properties, latent energies and processes, i.e. using its structure and dynamics the landscape has the ability to meet the needs of society'. Later, Bastian and Schreiber (1994) formulated the concept of ecological potential that derives from the ecosystem and its functions (landscape potential is formulated environmentally, thus anthropocentrically - on a sustained basis).

In Slovakia, the issue of landscape potential has gained more significant place in the 1980s and 1990s of the 20th century. Understanding the issue of landscape potential from physico-geographical point of view is explained by Ivanička (1983) 'in the physical geography the landscape potential includes all potential resources and reserves arising from a natural complex. This complex also includes the physical works of a man without social and economic activities, management systems, culture, psychology and other elements of the society'. According to Mazúr et al. (1980), the landscape potential is a set of preconditions a landscape might have. It expresses the landscape's ability to perform the functions a man may require. Otahel' and Poláčik (1987) understood the landscape potential as 'an offering, ability or suitability of the country to supply and fulfil different functions to meet the needs of the society in accordance with the harmonious functioning of the landscape'. According to Čech and Drdoš (2009), the landscape potential reflects a landscape's ability to provide a natural resource or a set of resources for further use. Such use, however, affects other resources as well. The concept of landscape potential is not limited only to the properties of the natural landscape, but it also includes socio-economic aspects, that is, it is based on geographical concepts of the landscape. Another example of the natural potential is offered by Hronec et al. (2010): Natural potential of each area or each type of a landscape is a possibility or opportunity to develop the given area. It is also a concept that relates to the concept of natural resources and takes into account the whole natural complex of the landscape. It is, therefore, the sum of all landscape features that create conditions for economic appreciation of the country. Potential assessment of the landscape is often associated with the use of the territory. On this basis, the methodology LANDEP was developed (Ružička, Miklós, 1982; Hrnčiarová, 1999).

According to Mannsfeld (1983), potential assessment should contain information about the landscape type, the degree of activities appropriateness, the degree of availability, the degree of burden, burden threshold (sensitivity and intensity thresholds for each activity), the type of possible conflicts and mitigation measures. The issue of landscape potential, according to Hrnčiarová (2005), needs a research focused on those landscape features that affect the spatial organisation of the land use. Therefore, the potential assessment includes a number of other procedures, such as the landscape's stability, burden, vulnerability, significance, variability, susceptibility, diversity, sensitivity to anthropogenic influences and the like that influence the potentials which in turn influence limits of landscape development, that is, determine the thresholds of environmental-friendly utilisation rate of the landscape by people. According to Lehotský (1991), during the evaluation process, we attach certain values to potentials, each representing a certain positive attribute or a source of properties, optionally limiting attributes and limits to their use. The outcomes are sets of similar landscape types. One or several landscape types with common characteristics against the proposed activity makes the value level. Knowing the potential of the landscape thus includes several scientific assumptions and steps (Lehotský, 1991): 
- choosing relevant data in accordance with the given goal of the work, research details and details visible on the map,

- choosing data collection fields,

- choosing relevant information in terms of the importance of landscape elements or their properties against the considered functions,

- own assessment.

Landscape potential is assessed in relation to society's activities, thus allowing us to distinguish and evaluate partial potentials of the landscape. Landscape planning in Germany (Izakovičová et al., 1997) distinguishes the following kinds of potentials:

1. the potential for recreation and relaxation - where people can relax,

2. biotic production potential - the ability of a landscape to ensure production of biomass (wood, food),

3. water supplies potential - landscape's ability to generate renewable groundwater or surface water resources,

4. raw material potential - landscape's ability to provide ore and nonmetallic,

5. construction potential - the ability of a landscape to provide space for the construction (usually, there is no distinction between the construction of residential buildings, industrial, agricultural and transport equipment. This differentiated assessment includes the assessment of environmental impact),

6. the potential for locating landfills - landscape's ability to accept foreign substances without having to penetrate into the system of relationships between its elements,

7. biotic regenerative potential - the presence of protected, endangered, rare plant and animal species, communities, habitats and landscape types,

8. climate regenerative potential - landscape's ability to provide fresh air in heavily industrialised areas,

9. energy potential - landscape's ability to provide a variety of sources for energy production.

One of the partial landscape potentials is the potential for the use of water resources (hydrological potential). According to Dokoupil and Matúšková (2005), the process of determining the landscape's potential is affected primarily by the amount of water present in the area (i.e. the assessment of quantity) and it quality. Such process is closely related to the hydrological regime whose assessment is important because the amount of water varies through time. Water ensures environmental stability of the landscape and also proper functioning of geosystems. For the needs of the regional development, the assessment of water resources is based on the Directive 2000/60 EC of the European Parliament and the Council establishing a framework for Community action in the field of water policy. This Directive is also valid for the Slovak Republic. From the point of view of regional development, we need to assess in particular the status of water with emphasis on ecological and chemical status of water and its quantitative characteristics as well. The assessment should be based on individual river basin plans, taking into account the summary of significant anthropogenic impacts, especially pollution sources (Dokoupil, Matušková, 2005).

Otahel' and Poláčik (1987) also distinguished several potentials - including water management potential based on ground and surface waters. The basic criterion for marking a potential are hydrogeological conditions that are classified in four categories based on aquifers, whilst the fundamental information is an indication of medium yields from springs. In terms of surface 
water, the highest value is obtained by static supplies of surface water (ponds). Dynamic surface water supplies are assessed on the basis of the average discharge of waterways.

The aim of this paper is to analyse the landscape potential of the micro-region Mincol for water management based on surface waters. Based on the chosen methodology using selected grading criteria and by summing up the point values, we arrived at five degrees of landscape potential suitability for water management with respect to surface water.

\section{Methods}

Hydro-analysis is carried out based on information sources on flowing surface water from materials provided by SHMU Košice. Custom fieldwork consisted of mapping the sources, monitoring the depth of ground water levels in wells and the depth levels of surface water, gravel pits and clays, determining the discharge of small waterways without the measuring network using only qualified estimates.

To provide the most detailed assessment of the potential, a basic square evaluation grid (square dimensions $-0.5 \mathrm{~km}^{2}$ ) has been created in GIS environment, copying the area of the micro-region accounting to $125.92 \mathrm{~km}^{2}$. The assessment produced a total of 559 squares. This grid was then added as an additional layer to the individual analytical maps. Within each square were assigned standard point values for each attribute whose assessment is relevant for the given type of the landscape potential. For the purpose of the assessment, decisive criteria were selected and the significance (values) of individual criteria (classifiers) was identified. Classifiers whose assessment is essential for the given type of potential were ranked in terms of significance as shown in Table 1 . Then we calculated the value of classifiers $\left(\mathrm{W}^{\mathrm{n}}\right.$ in Table 1 ), which was then multiplied by the value of the individual intervals of each classifier (Tables 2-4). In terms of potential assessment, the most important criterion is the static reserve of surface waters (i.e. artificial and natural lakes). The basic criterion for the assessment of dynamic resources of surface water is the average discharge. For the places with no hydrological measurements (especially on smaller rivers), the data were obtained through estimates of terrain analogous to the water flow data.

We then calculated the value of the water management potential (surface water for each square of $0.5 \mathrm{~km}^{2}$ ) according to the formula

$$
\mathrm{K}=\sum_{i=1}^{4} K_{1_{i}} \sum_{i=1}^{4} K_{1_{i}} \cdot W_{1}^{n} W_{1}^{n}+\sum_{i=1}^{5} K_{2_{i}} \sum_{i=1}^{5} K_{2_{i}} \cdot W_{2}^{n} W_{2}^{n}+\mathrm{K}_{3} \cdot W_{3}^{n} W_{3}^{n}
$$

Final values of potentials for each of the selected squares can be found in Table 5.

$\mathrm{T}$ a b le 1 . The calculation of values of the selected localisation assumptions regarding water management (surface water).

\begin{tabular}{|c|c|c|c|c|c|c|}
\hline $\mathbf{r}$ & $\mathbf{j}$ & Classifiers & $\mathbf{k}_{\mathrm{ri}}$ & $\mathbf{k}_{\mathrm{ri}}^{\mathrm{s}}$ & $\mathbf{W}_{\mathrm{j}}$ & $\mathbf{W}_{j}^{\mathrm{n}}=\mathbf{W}_{\mathrm{j} / \mathrm{s}}$ \\
\hline 1 & 1 & $k_{\mathrm{li}}$, annual average discharge & 1 & 1 & 3 & 0.500 \\
\hline 2 & 2 & $k_{2 \mathrm{i}}$, waterway rank & 2 & 2 & 2 & 0.333 \\
\hline 3 & 3 & $k_{31}$, the occurrence of static surface waters resources & 3 & 3 & 1 & 0.167 \\
\hline
\end{tabular}

Notes: $\mathrm{k}_{\mathrm{ri}}$, simple order of significance; $\mathrm{k}_{\mathrm{ri}}^{\mathrm{s}}$, standardised order of classifiers; $\mathrm{W}_{\mathrm{j}}$, value of classifiers; $\mathrm{W}_{\mathrm{j}}^{\mathrm{m}}$, standardised value of characters, $\mathrm{y}=\left(\mathrm{W}_{1}+\mathrm{W}_{2}+\mathrm{W}_{3}\right)$.

T a b l e 2. The average annual discharge of the potential regarding water management(surface water).

\begin{tabular}{|c|l|c|c|c|c|}
\hline $\mathbf{i}$ & Classifier $\mathbf{k}_{1 \mathbf{i}}$ & $\mathbf{k}_{\mathbf{l i}}$ & $\mathbf{k}_{{ }_{\mathbf{l i}}}$ & $\mathbf{K}_{\mathbf{l i}}$ & $\mathbf{K}_{\mathbf{l i}} \cdot \mathbf{W}^{\mathbf{n}}$ \\
\hline 1 & $0.01-0.20 \mathrm{~m}^{3} / \mathrm{s}$ & 4 & 4 & 1 & 0.5 \\
\hline 2 & $0.21-0.40 \mathrm{~m}^{3} / \mathrm{s}$ & 3 & 3 & 2 & 1 \\
\hline 3 & $0.41-0.60 \mathrm{~m}^{3} / \mathrm{s}$ & 2 & 2 & 3 & 1.5 \\
\hline 4 & 0.61 and $\mathrm{more} \mathrm{m}^{3} / \mathrm{s}$ & 1 & 1 & 4 & 2 \\
\hline
\end{tabular}

Notes: $\mathrm{k}_{\mathrm{li}}$, simple order of significance; $\mathrm{k}_{\mathrm{li}}^{\mathrm{s}}$, standardised order of classifiers; $\mathrm{K}_{\mathrm{li}}$, value of classifiers 
T a b l e 3. Waterways' ranking (Strahler, 1952) for water management potential (surface water).

\begin{tabular}{|c|l|c|c|c|c|}
\hline $\mathbf{i}$ & ${\text { Classifier } \mathbf{k}_{2 \mathbf{i}}}$ & $\mathbf{k}_{2 \mathbf{i}}$ & $\mathbf{k}_{2 \mathbf{i}}^{\mathbf{s}}$ & $\mathbf{K}_{2 \mathbf{i}}$ & $\mathbf{K}_{2 \mathbf{i}} \cdot \mathbf{W}^{\mathbf{n}}$ \\
\hline 1 & Waterways of the $1^{\text {st }}$ rank & 5 & 5 & 1 & 0.333 \\
\hline 2 & Waterways of the $2^{\text {nd }}$ rank & 4 & 4 & 2 & 0.666 \\
\hline 3 & Waterways of the $3^{\text {rd }}$ rank & 3 & 3 & 3 & 0.999 \\
\hline 4 & Waterways of the $4^{\text {th }}$ rank & 2 & 2 & 4 & 1.332 \\
\hline 5 & Waterways of the $5^{\text {th }}$ rank & 1 & 1 & 5 & 1.665 \\
\hline
\end{tabular}

T a b le 4. The occurrence of static surface water reserves for water management potential (surface water).

\begin{tabular}{|l|c|c|c|c|}
\hline Classifier $\mathbf{k}_{3 \mathrm{i}}$ & $\mathbf{k}_{3 \mathrm{i}}$ & $\mathbf{k}_{3 \mathrm{i}}^{\mathbf{s}}$ & $\mathbf{K}_{3 \mathbf{i}}$ & $\mathbf{K}_{3 \mathrm{i}} \cdot \mathbf{W}^{\mathbf{n}}$ \\
\hline Occurrence & 1 & 1 & 1 & 0.167 \\
\hline
\end{tabular}

T a b l e 5. Resulting point value of the potential for some squares.

\begin{tabular}{|c|c|c|c|c|}
\hline $\begin{array}{c}\text { Location } \\
\text { of the square }\end{array}$ & Waterway ranking & Discharge & $\begin{array}{c}\text { The occurrence of static surface } \\
\text { water reserves }\end{array}$ & potential \\
\hline I14 & 1.665 & 2 & 0.167 & 3.8 \\
\hline I15 & 0.666 & & 0.167 & 0.8 \\
\hline I16 & 1.665 & 2 & 0.167 & 3.8 \\
\hline I17 & 0.999 & 1.5 & & 2.5 \\
\hline I18 & 0.666 & 0.5 & & 1.2 \\
\hline
\end{tabular}

\section{Analysis of hydrological conditions in the Minčol micro-region}

The micro-region Minčol (Fig. 1) is located in the northern part of Slovakia, municipality of Stará Lubovňa, and occupies geomorphological units Čergov, Lubovnianske highlands and Spišsko-šarišské highlands. The micro-region covers an area of $125.92 \mathrm{~km}^{2}$.

The river system in the micro-region is relatively dense (Fig. 2). Through the micro-region leads the main European watershed, whilst Lipiansky stream, Večný stream, Podrožný stream and Napravjany creek belong to the drainage basin of Torysa and Topla flowing into the Black Sea. Other remaining waterways are part of the Poprad drainage basin, flowing into the Baltic Sea. Tops Malý Minčol (1,045 $\mathrm{m}$ above sea level) and Minčol (1,157 $\mathrm{m}$ above sea level) in Čergov are in this respect a very important hydrological site. On the eastern slopes originates Topla. The entire north ridge of Čergov belongs to the main European watershed (Fig. 6).

The streams flowing east of the urban area Obručné such as Podrožný stream or Večný stream belong to the drainage basin of Topla along with Lipiansky (Sokolí) stream, forming south-east border of the micro-region Minčol.

The hydrographic axis of the micro-region is the river Poprad (Fig. 3) that originates in the High Tatras at the height of 1,310 m above sea level. Poprad river is a confluence of the creek Hincovo and Krupná, which flows from the Poprad tarn. River Poprad forms 5-km long natural state border with Poland and flows $16 \mathrm{~km}$ through the micro-region Minčol. Its water regime consists of snow-rain type of water supply. The river is most rich in April, and the lowest water levels are reached in January. The average annual discharge at Chmel'nica is $15.8 \mathrm{~m}^{3} / \mathrm{s}$ (SHMÚ, 2003) (Fig. 5). Total average monthly discharges from 2000 to 2009 are shown in Table 6 and Figure 4. From Chmelnica to Plaveč, the Poprad valley is characterised by inversion. Its bed is based on the erosion-denudation furrow of the anticlinoria klippen belt (Lukniš et al., 1972). The flow of the river has NE course. From Čirč, it turns to the NW where it forms the state border with Poland. Poprad annually transports large amounts of sediment, especially in the section Plaveč-Orlov. Its tributaries such as Lubotínka, Soliská or Chotárny stream originate in Lubovnianska Highlands and Čergov.

The most important right tributary of Poprad is Lubotínka, with a total length of $3.5 \mathrm{~km}$. The stream is a confluence of two smaller streams - Dedinská voda and Hradlová. The average annual discharge is $0.630 \mathrm{~m}^{3} / \mathrm{s}$ (SHMÚ, 2003). 


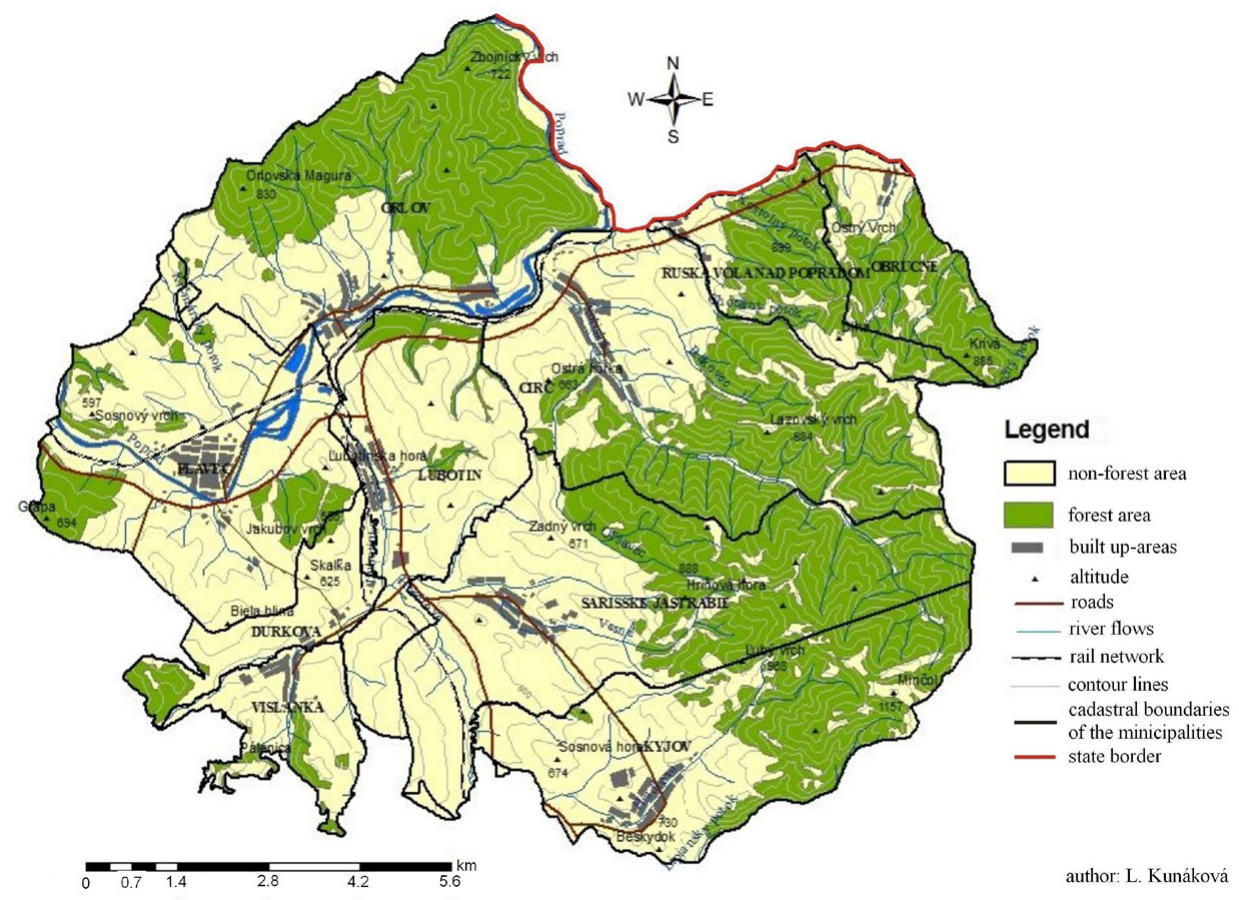

Fig. 1. General geographical map of the micro-region Minčol.

Hradlová stream with an average annual discharge of $0.155 \mathrm{~m}^{3} / \mathrm{s}$ (SHMÚ, 2003) originates in the saddle under Minčol at an altitude of $1,000 \mathrm{~m}$ above sea level. It flows through Kyjov in partly adjusted bed, and there it turns to the west. Further it flows through the village Pusté Pole, its bed is full of silt there. Then it changes the direction of its flow to the north and meanders. Beaver dam on the river in this area is the sign of its pure water. The stream is fierce, often changes the position of its bed and cuts deep into the soil. The stream is $12 \mathrm{~km}$ long. Near the confluence with Dedinská voda, it also takes up the stream Vesné. Vesné originates at an altitude of $900 \mathrm{~m}$ above sea level, northeast of Hriňová mountain ( $888 \mathrm{~m}$ above sea level), flows westward and flows through the centre of the village Šarišské Jastrabie. The stream is partly regulated. Hradlová flows into Lubotínka near the national road at the crossing of the village Šarišské Jastrabie and Durková at an altitude of $510 \mathrm{~m}$ above sea level. Dedinská voda springs up at a height of $700 \mathrm{~m}$ above sea level in Hromovce and runs through the villages Vislanka and Durková. The stream brings with itself a large amount of gravel after each rainfall. After water subsides, the material forms deposits. Therefore, the stream changes its bed very often. The height difference between the mouth and the source is $200 \mathrm{~m}$.

Another right tributary of Poprad is the stream Soliská with the length of $10 \mathrm{~km}$, originating under Minčol at an altitude of $950 \mathrm{~m}$ above sea level. The stream flows in NW direction, has a cascade river network and picks up some short tributaries from Čergov. From the source to the mouth, it overcomes $485 \mathrm{~m}$ height difference. After substantial rainfalls, the stream causes flooding in the village. Soliská stream is also unusual in that $70 \%$ of its total catchment area is occupied by forests. Olšavec stream originates east of Hriňová at Šarišské Jastrabie, at an altitude of 956 above sea level. It flows north, its length is $5.2 \mathrm{~km}$, and at the boundary of the village Čirč it flows into Soliská at an altitude of $505 \mathrm{~m}$ above sea level. From the source to the mouth, the stream overcomes the altitude difference of up to 450 $\mathrm{m}$. Rakovec is a right tributary of Soliská, the flow length is $4.5 \mathrm{~km}$. It originates in an altitude of $900 \mathrm{~m}$ above sea level northeast of Lazovský hill. 


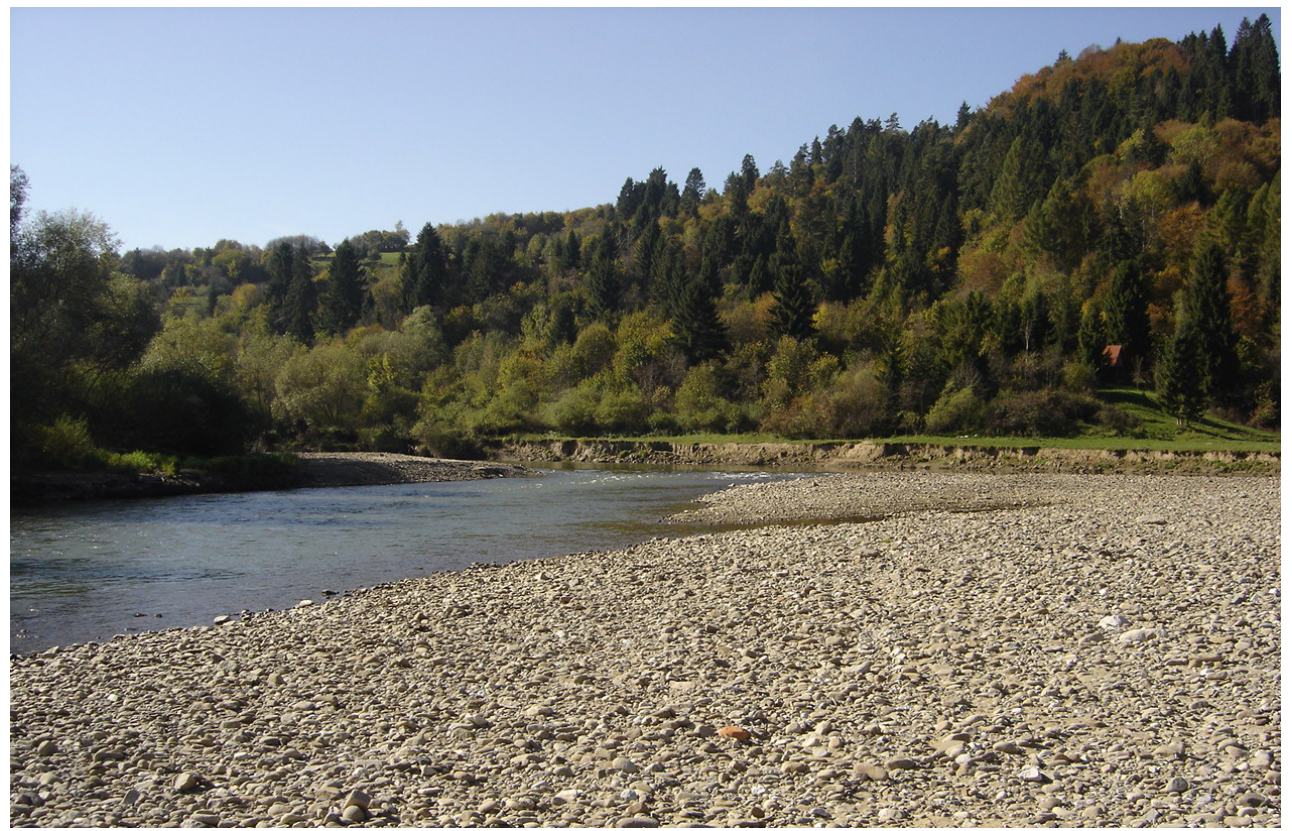

Fig. 2. Poprad river bench at the time of the hot summer months.

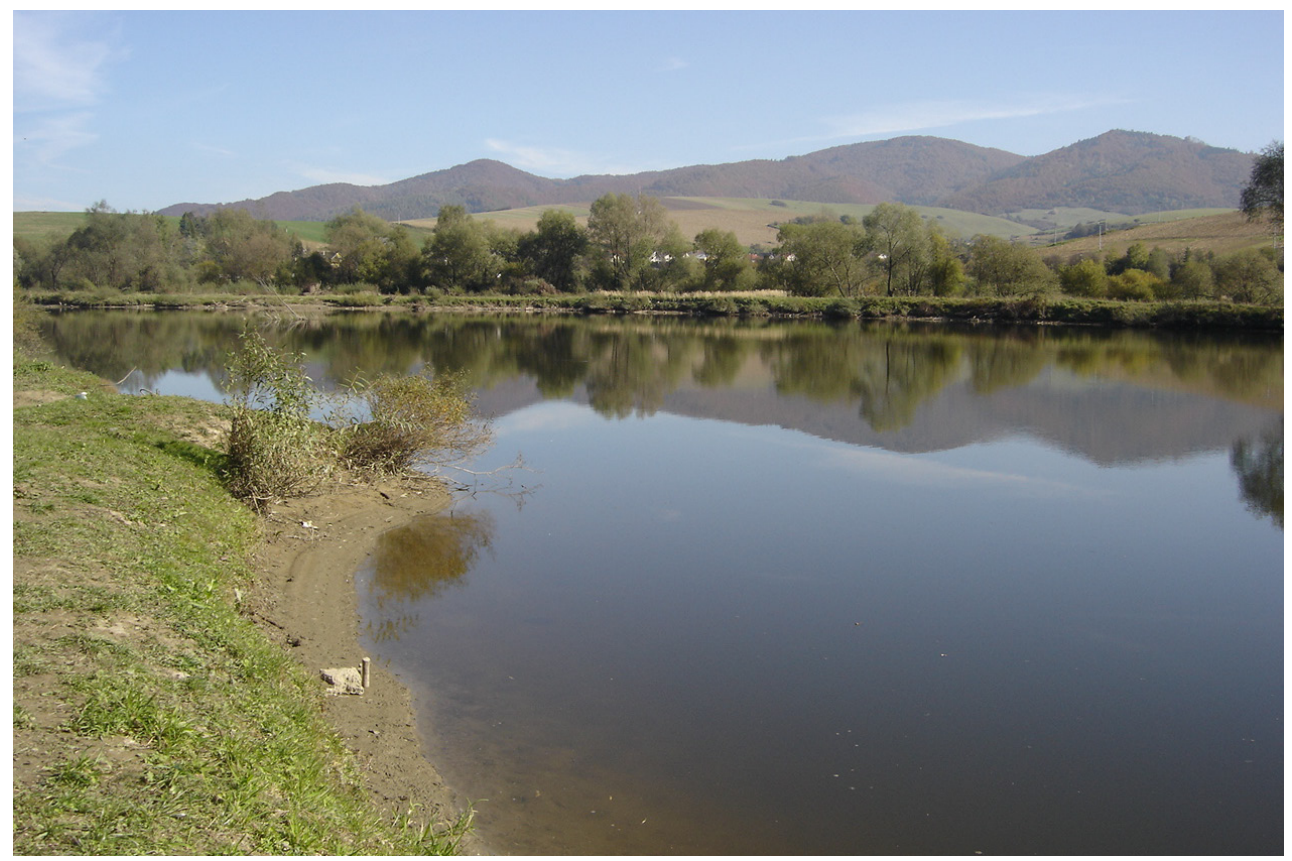

Fig. 3. Andrejovský pond.

\section{4}


Another right tributary of the river Poprad is the river Smereczek, which forms the northern border of the micro-region and also the state border with Poland. Its left tributary is Kostolný potok, and in the village Ruská Vola above Poprad, it takes up Chotárny potok $5.2 \mathrm{~km}$ long. It originates at an altitude of $925 \mathrm{~m}$ above sea level, south of Dlhá in Čergov, and flows NW direction.

Poprad's left tributary is Krčmársky potok, flowing to the Poprad near the village Plaveč. From Lubovnianske highlands, the river Poprad takes up other nameless smaller streams.

In terms of artificial water bodies, the micro-region has six ponds (Danube salmon, trout, grayling or barber) located along Poprad, all of which are used as a breeding ground. The biggest of them is in the area Andrejovka (local part Orlova) and functions as a recreational retreat (Fig. 3).

The newly created water area is located near the main road between the villages Lubotín and Plaveč. At present, gravel mining takes place (Fig. 4).

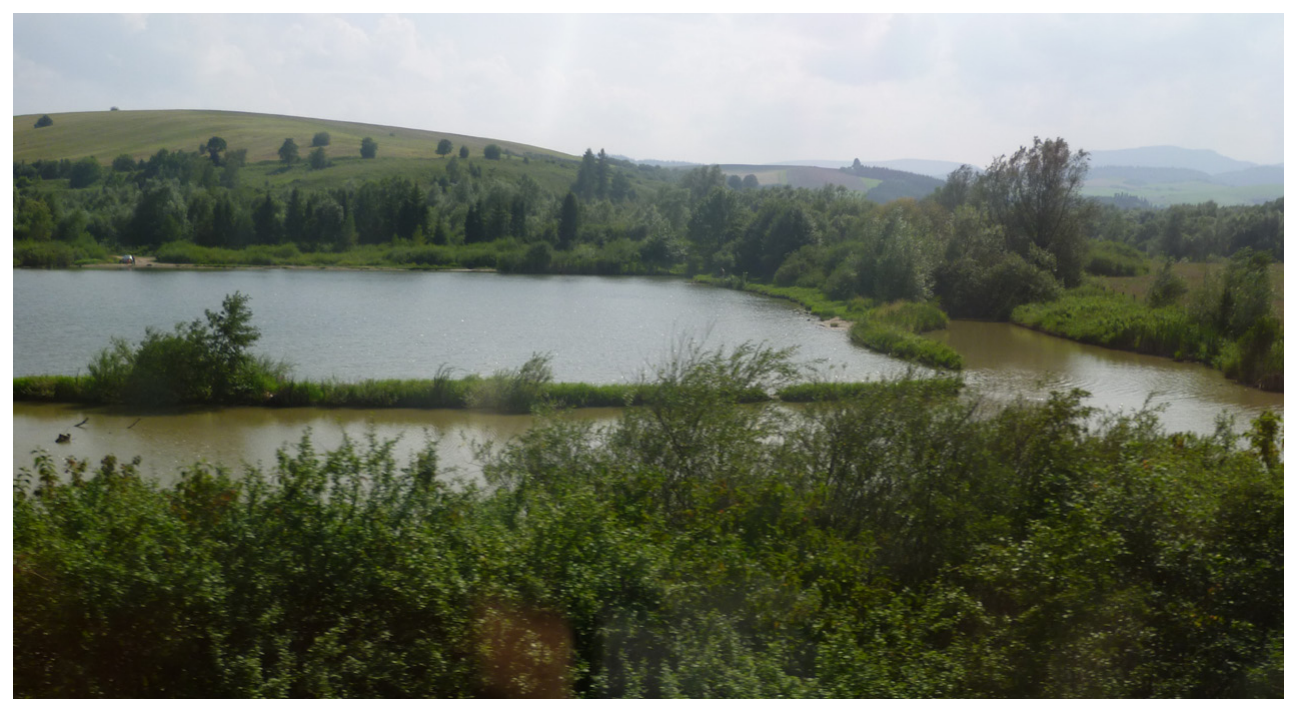

Fig. 4. System of ponds near Plaveč.

T a b l e 6. The average discharge and outflows of the Poprad river for the period 2000-2008.

\begin{tabular}{|l|l|c|c|c|c|c|c|c|c|c|c|c|c|}
\hline Station name & Month & $\mathbf{1}$ & $\mathbf{2}$ & $\mathbf{3}$ & $\mathbf{4}$ & $\mathbf{5}$ & $\mathbf{6}$ & $\mathbf{7}$ & $\mathbf{8}$ & $\mathbf{9}$ & $\mathbf{1 0}$ & $\mathbf{1 1}$ & $\mathbf{1 2}$ \\
\hline Chmelnica & Discharge $\left(\mathrm{m}^{3} / \mathrm{s}\right)$ & 6.25 & 8.46 & 20.8 & 24 & 23.1 & 22.9 & 26.2 & 18.1 & 12.1 & 11 & 9.16 & 7 \\
\hline (Poprad) & Outflow $(\%)$ & 3.4 & 4.2 & 11.2 & 13 & 12.4 & 12 & 14.1 & 9.7 & 6.3 & 5.9 & 4.8 & 3.7 \\
\hline
\end{tabular}

Source: SHMU Košice

\section{Results}

The resulting point score in each square belongs to a particular degree of suitability of landscape's potential for water management based on its surface waters (Fig. 7). The potential was divided into five degrees (intervals):

1. very unfavourable potential - this type of potential takes up space without any surface water network. This type of landscape is the largest in Spišsko-šarišské highlands and takes up a coherent area in Čergov, Lubovnianske highlands and Hromovec. 
Monthly annual discharge $\left(\mathrm{m}^{3} / \mathrm{s}\right)$ of Poprad river for the period 2000-2008

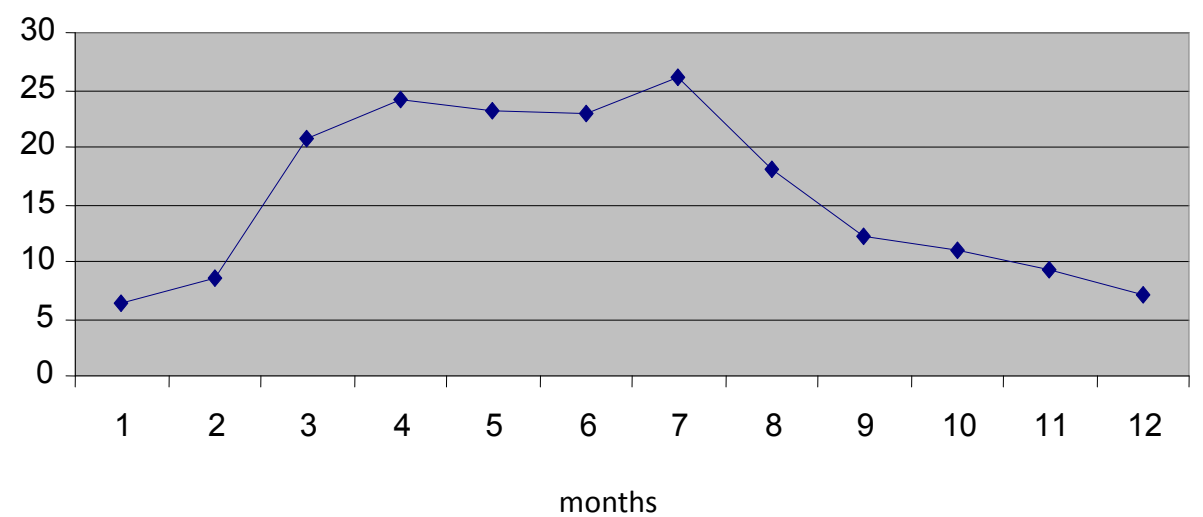

Fig. 5. Monthly annual discharge $\left(\mathrm{m}^{3} / \mathrm{s}\right)$ of Poprad river for the period 2000-2008.

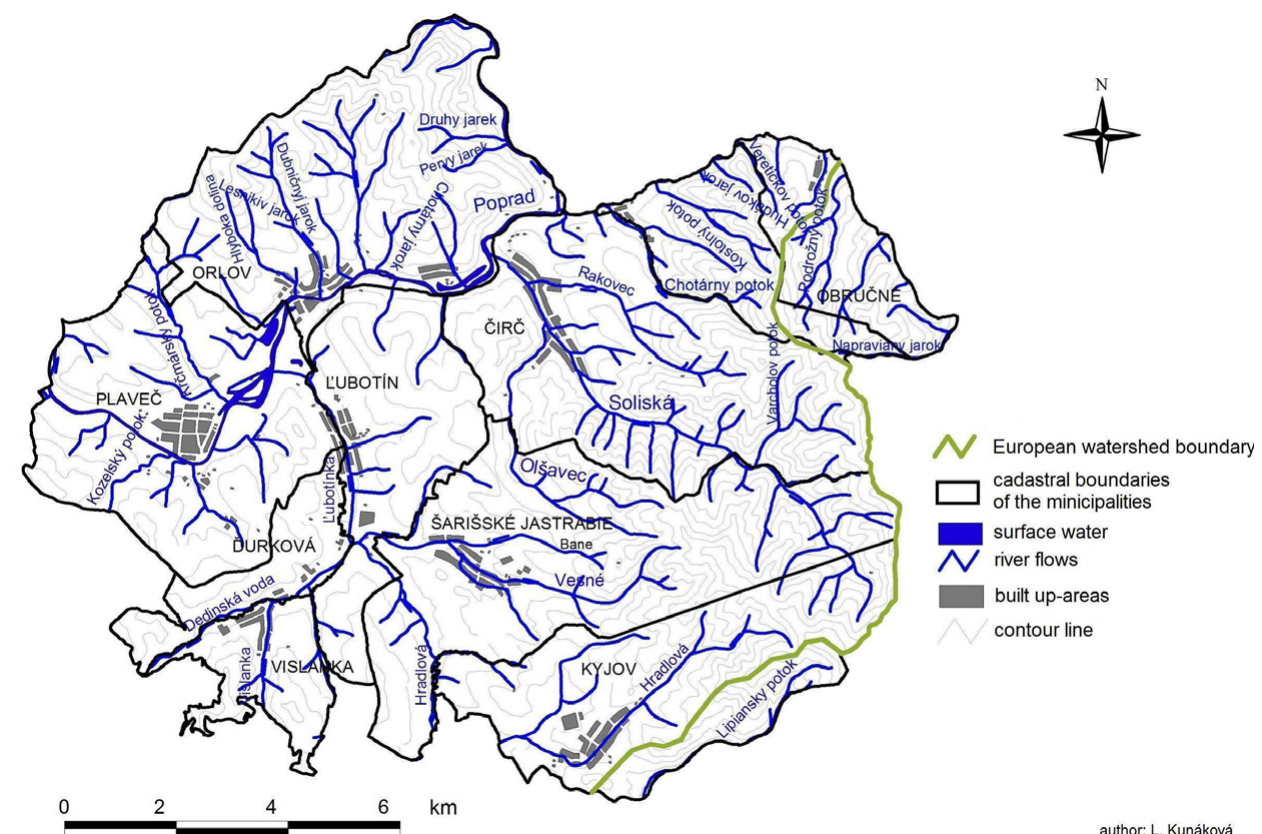

Fig. 6. Surface waters of Minčol micro-region. 


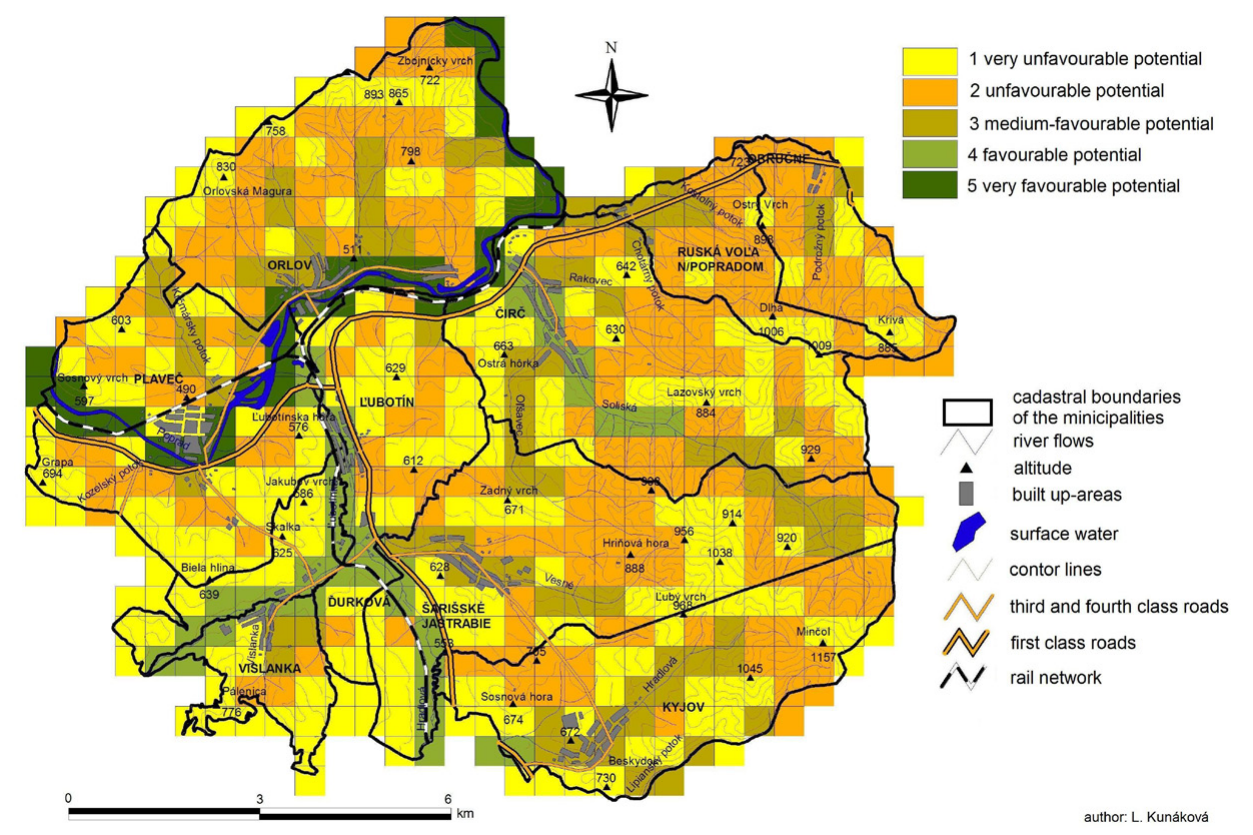

Fig. 7. Potential of micro-region Minčol for water management based on its surface waters.

2. unfavourable potential - this type of potential is spatially most extensive. The largest areas are found in Čergov and Lubovnianske highlands. This potential encompasses the upper headwater areas of several waterways or short streams in steep slope valleys. There are no static sources of surface water; there are mostly waterways of the first rank and their average discharge is at the lowest interval $0.01-0.20 \mathrm{~m}^{3} / \mathrm{s}$.

3. moderately favourable potential - its area is significantly different. It occupies the central part of larger waterways (Soliská, Vesné, Hradlová, Lipianský potok, Olšavec, Rakovec, Kostolný potok, Podrožný potok, Krčmársky potok). There are surface water supplies. The average discharge is in the range $0.21-0.40 \mathrm{~m}^{3} / \mathrm{s}$. Waterways falling within this potential are usually of the second rank.

4. favourable potential - this type of potential takes up the smallest area and includes the valley of Lubotínka stream and its two most important tributaries, Dedinská voda and Hradlová as well as the lower regions of the stream Soliská. In terms of static supplies of surface water, this type of potential boasts with Lubotínske ponds located in the administrative area of Plaveč. Dedinská voda, Hradlová and Soliská are waterways of third rank and Lubotínka is of fourth rank. The average discharge of Dedinská voda is $0.31 \mathrm{~m}^{3} / \mathrm{s}$, Hradlová $0.155 \mathrm{~m}^{3} / \mathrm{s}$ and Lubotínky $0.630 \mathrm{~m}^{3} / \mathrm{s}$ (SHMÚ, 2003).

5. very favourable potential - this type of the landscape potential is situated along the river 
Poprad. Its average discharge at Chmel'nica is $15.8 \mathrm{~m}^{3} / \mathrm{s}$. Poprad is a waterway of the fifth rank. This type of potential means significant reserves of surface water: Andrejovka pond in the cadastral area of Orlov and Plavečské deposits gravel in the administrative area of Plaveč.

\section{Conclusion}

Landscape potential can be assessed in several ways; for example, there is an assessment of partial landscape's potentials. One of these potentials is the potential for water management based on surface waters. This potential reflects static and dynamic reserves of surface waters contained in rivers, lakes and artificial reservoirs. By using appropriate methodology, we can qualitatively and quantitatively express the suitability of individual landscape areas for the purpose of this type of potential. We are, therefore, predicting possible potential economic use of the landscape and envisioning the development of the specific landscape units.

There are several inhabited places in the micro-region Minčol through which streams flow. It is important to preserve rivers and streams in their natural state or restore their function (see biocorridors' role). Natural course of streams' flow should be retained. In the immediate vicinity of settlements, where it is often not possible, river banks should be regulated in a manner close to nature. Formation of steep and flat riversides, as well as sections with a different flow rate, should be left to natural development to promote the diversity of living space (Aulig, Klingberg, 1991).

Minčol micro-region is from the point of view of surface water supplies very differentiated. In Spišsko-šarišské highlands, due to geology, landforms and other factors, the river network is underdeveloped. The dominant watercourse is Lubotínka with its major tributaries: Hradlová, Dedinská voda and Vesné. An exception in terms of importance, water levels and other indicators is the river Poprad, whose hydropower potential may be used in future. Čergov mountains and Lubovnianska highlands are rich in rivers, but most of the time these are short slope rivers with a low flow, some of which are only seasonal. The most important is Soliská stream. The region along river Poprad is rich in ponds and gravel pits.

Given the nature the micro-region's river network, the most favourable type of potential is found only in the valley of the river Poprad because of its discharge and other indicators. Only the river Poprad provides good conditions for the use of this type of potential. Preferably, this type of potential should be used in areas not burdened by mining and quarrying activities (sand and gravel) and outside of inhabitable areas. These conditions are met in two particular areas: west of Plaveč at micro-region's borders and along the state border with Poland.

The second most favourable potential was found around Lubotínka's riverbank and two of its major tributaries. The use of these areas is significantly limited by both low average discharge of the surface water flows and relatively dense settlement. Greater opportunities are provided by still bodies of water - the area Lubotínske ponds in the cadastral area of Plaveč.

Acknowledgements

Contribution is a part of the Project VEGA 1/0749/14 and KEGA 020PU-4/2015. 


\section{References}

Aulig, G. \& Klinberg T. (1991). Základy ekologie vesnice. Obnova vesnice. Praha: Ministerstvo pro místni rozvoj ČR.

Barsch, H. (1980). Naturraumpotentiale - ihre kennzeichnung und nutzung in der DDR. Zeitschrift für den Erdkundeunterricht, 32(8/9), 305-318.

Bastian, O. \& Schreiber K.F. (Eds.) (1994). Analyse und ökologische bewertung der landschaft. Jena: Fischer.

Čech, V. \& Drdoš J. (2009). Geoekológia a environmentalistika I: náuka o krajine, jej predmet a metodika skúmania. Prešov: FHPV PU.

Dokoupil, J. \& Matúšková A. (2005). Rozvojový potenciál Plzeňského kraje. Plzeň: Pedagogická fakulta Západočeskej university.

Graf, D. (1976). Ökonomische bewertung von naturpotentialen und naturresourcen. Geographische und ökologische Grundlagen der Landschaftsplanung, Mitteilungsblatt, 13.

Haase, G. (1964). Landschaftsökologische untersuchungen und naturräumliche gliederung. Petermanns Geographische Mitteilungen, 108, 8-30.

Haase, G. (1978). Zur ableitung und kennzeichnung von naturpotentialen. Petermanns Geographische Mitteilungen, 122(1), 113-125.

Haase, G. (Ed.), (1991). Naturraumerkundung und landnutzung. Geochorologische verfahren zur analyse, kartierung und bewertung von naturräumen. Beiträge zur Geographie, 34/1.

Hrnčiarová, T. (1999). Krajinnoekologické plánovanie pomocou metodiky LANDEP a metodiky EÚK. Geografický Časopis, 51(4), 399-413.

Hrnčiarová, T. (2005). Stanovenie krajinnoekologického potenciálu pre rozvoj mesta Bratislava. Acta Environmentalistica Universitas Comenianae (Bratislava), 13(1), 39-46.

Hronec, O., Boltižiar, M., Bujnovský, R., Michaeli, E., Mindáš, J., Schwarzová, H. \& Tomeková B. (2010). Manažment a oceňovanie prírodných zdrojov. Skalica: Stredoeurópska vysoká škola.

Ivanička, K. (1983). Základy teórie a metodológie socioekonomickej geografie. Bratislava: SPN.

Izakovičová, Z., Miklós, L. \& Drdoš J. (1997). Krajinnoekologické podmienky trvaloudržatelného rozvoja. Bratislava: Veda, vydavatel'stvo SAV.

Jäger, K.D. \& Hrabowski K. (1976). Zur strukturanalyse von anforderungen der gesellschaft an den naturraum, dargestellt am beispiel des bebauungspotentials. Petermanns Geographische Mitteilungen, 120(1), 29-37.

Jäger, K.D., Mannsfeld, K., Haase, G., Hartsch, I., Schlüter, H., Kopp, D., Linke, H., Barsch, H., Knothe, D., Arnold, K.H., Hrabowski, K. \& Schulze J. (1977). Bestimmung von partiellen und komplexen potentialeigenschaften für chorische naturraumeinheiten (methodik, beispielsuntersuchungen). Forschungsbericht G2. Leipzig: Sächsische Akademie der Wissenschaften.

Lehotský, M. (1991). Funkčné štruktúry krajiny (Štiavnické vrchy). Bratislava: Veda, vydavatelstvo SAV.

Leser, H. (1997). Landschaftsökologie: ansatz, modelle, methodik, anwendung. Stuttgart: Ulmer.

Lukniš, M. et al. (1972). Slovensko II. Bratislava: Príroda, Obzor.

Mannsfeld, K. (1978). Zur kennzeichnung von gebietseinheiten nach ihren potentialeigenschaften. Petermanns Geographische Mitteilungen, 122(1), 17-27.

Mannsfeld, K. (1979). Theoretische und methodische probleme bei der kartierung von naturraumpotentialen. Contemporary geography and integrated landscape research (pp. 218-231). Bratislava: SAV.

Mannsfeld, K. (1983). Landschaftanalyse und ableitung von naturraumpotentialen. Berlin: Akademie Verlag.

Mazúr, E., Drdoš, J. \& Urbánek J. (1980). Krajinné syntézy a ich význam pre tvorbu priestorových štruktúr životného prostredia. Životné Prostredie, 14(2), 66-70.

Mosimann, T. (1984). Methodische grundprinzipien für die untersuchung von Geoökosystemen in der topologischen dimension. Geomethodica, Veröff. 9. Basler Geometh. Coll., Bd.9, 31-65.

Neef, E. (1963). Topologische und chorologische arbeitsweisen in der landschaftforschung. Petermanns Geographische Mitteilungen, 107, 249-259.

Neef, E. (1966). Zur frage des gebietswirtschaftlichen potentials. Forschungen und Fortschritte, 40, 65-96.

Otahel', J. \& Poláčik Š. (1987). Krajinná syntéza Liptovskej kotliny. Bratislava: Veda, vydavatel'stvo SAV.

Ružička, M. \& Miklós L. (1982). Landscape-ecological planning (LANDEP) in the process of territorial planning. Ekológia (ČSSR), 1(3), 297-312.

SHMÚ (2003). Podklady k realizácia ČOV (čističky odpadových vôd) pre obec Pusté Pole.

Strahler, A.N. (1952). Dynamics basis of geomorpohology. Geological Society of America Bulletin, 63, 923-938. 